\title{
ANTIMICROBIAL SUSCEPTIBILITY OF BORDETELLA AVIUM AND ORNITHOBACTERIUM RHINOTRACHEALE STRAINS FROM WILD AND DOMESTICATED BIRDS IN HUNGARY
}

\author{
Réka SzABÓ, Enikő WEHMANN and Tibor MAGYAR* \\ Institute for Veterinary Medical Research, Centre for Agricultural Research, \\ Hungarian Academy of Sciences, P.O. Box 18, H-1581 Budapest, Hungary
}

(Received 3 March 2015; accepted 28 October 2015)

\begin{abstract}
The antimicrobial susceptibility of 19 Bordetella avium and 36 Ornithobacterium rhinotracheale strains was tested by the Kirby-Bauer disk diffusion method, and the minimal inhibitory concentrations (MIC) of amoxicillin, doxycycline and erythromycin were also determined. Most $O$. rhinotracheale strains were resistant to nalidixic acid, sulphamethoxazole-trimethoprim and gentamicin, and were susceptible to ampicillin, chloramphenicol, spectinomycin and tilmicosin. All B. avium strains were resistant to ceftiofur and lincomycin and susceptible to doxycycline, gentamicin, polymyxin B, spectinomycin and sulphonamides. The MICs ranged widely for all three antibiotics tested against $O$. rhinotracheale strains, from $0.12 \mu \mathrm{g} / \mathrm{ml}$ to $32 \mu \mathrm{g} / \mathrm{ml}$ for amoxicillin and erythromycin, and from $0.6 \mu \mathrm{g} / \mathrm{ml}$ to $32 \mu \mathrm{g} / \mathrm{ml}$ for doxycycline. For B. avium isolates, the MIC values ranged from $\leq 0.03 \mu \mathrm{g} / \mathrm{ml}$ to $1 \mu \mathrm{g} / \mathrm{ml}$ for amoxicillin, from $\leq 0.03 \mu \mathrm{g} / \mathrm{ml}$ to $0.12 \mu \mathrm{g} / \mathrm{ml}$ for doxycycline and from $8 \mu \mathrm{g} / \mathrm{ml}$ to $16 \mu \mathrm{g} / \mathrm{ml}$ for erythromycin. These findings support the idea that the use of antibiotics in a region or a farm may affect antimicrobial resistance and underline the need for prudent application of antibiotic therapy based on proper antimicrobial susceptibility testing.
\end{abstract}

Key words: Ornithobacterium rhinotracheale, Bordetella avium, antimicrobial susceptibility

Ornithobacterium rhinotracheale and Bordetella avium are among the several causative agents of respiratory tract diseases leading to severe economic losses in the poultry industry worldwide.

Infection by $O$. rhinotracheale has been reported from wild birds and poultry from all over the world, causing respiratory disorders, growth depression and arthritis. The severity of clinical signs and the mortality rates are variable and are influenced by many environmental factors (van Empel and Hafez, 1999). In Hungary, the disease was first described by Tanyi et al. (1995) in four- to sixweek-old broiler flocks. Over the past few years, the occurrence of O. rhinotracheale infections has increased, while antibiotic treatment of the disease has become less effective (van Veen et al., 2001).

${ }^{*}$ Corresponding author; E-mail: magyar.tibor@agrar.mta.hu; Phone: 0036 (1) 467-4092 
Turkey rhinotracheitis (coryza), the disease caused by B. avium, is most frequently diagnosed in 2- to 6-week-old turkeys as a sudden onset of sneezing and clear nasal discharge, but it has been described in other avian species as well (Raffel et al., 2002). A recent report has stated that B. avium is the third-ranked infectious agent in a list of the most challenging health issues for the US turkey industry (Beach et al., 2012).

The goal of this study was to evaluate the antimicrobial susceptibility of 19 B. avium and 36 O. rhinotracheale strains and determine the minimal inhibitory concentrations (MIC) of amoxicillin, doxycycline and erythromycin against these isolates.

\section{Materials and methods}

\section{Strains}

The 36 O. rhinotracheale strains included in this study had been isolated in Hungary between 2009 and 2013 from diseased turkeys $(\mathrm{n}=28)$, chickens $(\mathrm{n}=4)$ and pigeons $(\mathrm{n}=2)$. One strain had been obtained from a healthy goshawk (Accipiter gentilis) and another from a sparrowhawk (Accipiter nisus). Thirteen out of the 19 B. avium strains originated from diseased turkeys $(\mathrm{n}=11)$ and a chicken $(\mathrm{n}=2)$ between 2004 and 2014 in Hungary. The six strains obtained from Germany in 1985 had been isolated from turkeys $(n=2)$, ducks ( $n=$ $1)$, a goose $(n=1)$, a partridge $(n=1)$, and one was of unknown host origin. Isolates were identified by species-specific polymerase chain reaction (PCR) (van Empel and Hafez, 1999; Register and Yersin, 2005) and stored at $-70{ }^{\circ} \mathrm{C}$ until further examination. Table 1 shows the properties of the strains examined.

\section{Table 1}

Properties of the Ornithobacterium rhinotracheale and Bordetella avium strains examined in this study

\begin{tabular}{|c|c|c|c|c|}
\hline \multirow{2}{*}{$\frac{\text { Isolate ID }}{\text { OR001 }}$} & \multicolumn{2}{|c|}{ Source } & \multirow{2}{*}{$\begin{array}{c}\text { Year of isolation } \\
2001\end{array}$} & \multirow{2}{*}{$\begin{array}{c}\text { Geographic origin } \\
\text { Békéscsaba }\end{array}$} \\
\hline & turkey & joint & & \\
\hline OR002 & turkey & lung & 2001 & N. A. \\
\hline OR004 & turkey & lung & 2009 & Iván \\
\hline OR005 & turkey & trachea & 2009 & Lövő \\
\hline OR006 & turkey & trachea & 2009 & Lövő \\
\hline OR007 & chicken & choana & 2009 & Szerencs \\
\hline OR008 & turkey & lung & 2010 & Ikervár \\
\hline OR009 & turkey & trachea & 2010 & Szarvas \\
\hline OR010 & turkey & trachea & 2010 & Szarvas \\
\hline OR011 & turkey & trachea & 2010 & Szarvas \\
\hline OR012 & turkey & trachea & 2010 & Szarvas \\
\hline OR035 & turkey & lung & 2001 & Kaposvár \\
\hline OR037 & turkey & lung & 2001 & Kaposvár \\
\hline
\end{tabular}


Table 1 continued

\begin{tabular}{|c|c|c|c|c|}
\hline \multirow{2}{*}{$\begin{array}{l}\text { Isolate ID } \\
\text { OR042 }\end{array}$} & \multicolumn{2}{|c|}{ Source } & \multirow{2}{*}{$\frac{\text { Year of isolation }}{2010}$} & \multirow{2}{*}{$\begin{array}{c}\text { Geographic origin } \\
\text { Szombathely }\end{array}$} \\
\hline & turkey & trachea & & \\
\hline OR043 & turkey & trachea & 2010 & Szombathely \\
\hline OR044 & turkey & trachea & 2010 & Szombathely \\
\hline OR045 & turkey & trachea & 2010 & Szombathely \\
\hline OR046 & chicken & trachea & 2010 & N. A. \\
\hline OR047 & pigeon & trachea & 2010 & Legyesbénye \\
\hline OR048 & pigeon & trachea & 2010 & Legyesbénye \\
\hline OR049 & goshawk & trachea & 2011 & Budapest \\
\hline OR050 & chicken & trachea & 2011 & Pest megye \\
\hline OR051 & chicken & trachea & 2011 & Pest megye \\
\hline OR052 & turkey & lung & 2011 & Szarvas \\
\hline OR053 & turkey & trachea & 2011 & Csabacsüd \\
\hline OR054 & turkey & trachea & 2011 & Csabacsüd \\
\hline OR055 & turkey & trachea & 2011 & Csabacsüd \\
\hline OR056 & turkey & trachea & 2011 & Csabacsüd \\
\hline OR057 & sparrowhawk & trachea & 2011 & Budapest \\
\hline OR058 & turkey & trachea & 2011 & Ács \\
\hline OR059 & turkey & trachea & 2012 & Rum \\
\hline OR060 & turkey & trachea & 2012 & Szarvas \\
\hline OR061 & turkey & trachea & 2012 & Iván \\
\hline OR062 & turkey & trachea & 2012 & Hunya \\
\hline OR063 & turkey & lung & 2013 & Nagygerezsd \\
\hline OR064 & turkey & lung & 2013 & Feketebézseny \\
\hline $\mathrm{Ba} 001$ & turkey & trachea & 2012 & Kiskunfélegyháza \\
\hline $\mathrm{Ba} 002$ & turkey & trachea & 2012 & Szarvas \\
\hline $\mathrm{Ba} 003$ & turkey & trachea & 2012 & Szarvas \\
\hline $\mathrm{Ba} 004$ & turkey & trachea & 2012 & Szarvas \\
\hline $\mathrm{Ba} 005$ & turkey & trachea & 2012 & Szarvas \\
\hline $\mathrm{Ba} 006$ & turkey & trachea & 2012 & Szarvas \\
\hline $\mathrm{Ba} 007$ & turkey & trachea & 2012 & Szarvas \\
\hline $\mathrm{Ba} 008$ & turkey & trachea & 2004 & N. A. \\
\hline $\mathrm{Ba} 009$ & partridge & N. A. & 1985 & Germany \\
\hline $\mathrm{Ba} 010$ & N. A. & N. A. & 1985 & Germany \\
\hline $\mathrm{Ba} 011$ & turkey & N. A. & 1985 & Germany \\
\hline $\mathrm{Ba} 012$ & turkey & N. A. & 1985 & Germany \\
\hline $\mathrm{Ba} 013$ & duck & N. A. & 1985 & Germany \\
\hline $\mathrm{Ba} 014$ & goose & N. A. & 1985 & Germany \\
\hline $\mathrm{Ba} 015$ & chicken & lung & 2011 & Darány \\
\hline $\mathrm{Ba} 016$ & turkey & trachea & 2012 & Kiskunmajsa \\
\hline $\mathrm{Ba} 017$ & turkey & lung & 2012 & N. A. \\
\hline $\mathrm{Ba} 018$ & chicken & sinus & 2014 & Jászberény \\
\hline $\mathrm{Ba} 019$ & turkey & sinus & 2014 & Császártöltés \\
\hline
\end{tabular}

N. A.: not available 
SZABÓ et al.

\section{Susceptibility testing}

The Kirby-Bauer disk diffusion method was used to determine the susceptibility of the $O$. rhinotracheale and $B$. avium isolates to the following antibiotics: amoxicillin $(10 \mu \mathrm{g}$, Biolab), ampicillin $(10 \mu \mathrm{g}$, Abtek), ceftiofur $(30 \mu \mathrm{g}$, Biolab), chloramphenicol (30 $\mu \mathrm{g}$, Abtek), ciprofloxacin (5 $\mu \mathrm{g}$, Abtek), doxycycline (30 $\mu \mathrm{g}$, Abtek), enrofloxacin (5 $\mu \mathrm{g}$, Abtek), erythromycin (10 $\mu \mathrm{g}$, Abtek), gentamicin (10 $\mu \mathrm{g}$, Abtek), lincomycin (15 $\mu \mathrm{g}$, Biolab), nalidixic acid (30 $\mu \mathrm{g}$, Abtek), oxytetracycline (30 $\mu \mathrm{g}$, Biolab), penicillin (10 units, Abtek), polymyxin B (300 units, Abtek), spectinomycin (100 $\mu \mathrm{g}$, Abtek), sulphamethoxazole-trimethoprim $(23.75+1.25 \mu \mathrm{g}$, Oxoid), sulphonamides (300 $\mu \mathrm{g}$, Oxoid) and tilmicosin $(15 \mu \mathrm{g}$, Biolab). The MICs of amoxicillin (Sigma), doxycycline (Sigma) and erythromycin (Sigma) were determined by broth microdilution in order to quantify the level of resistance and thus lay the foundations for investigating the genetic background of resistance to these antibiotics. Since standards have not yet been established for $O$. rhinotracheale and B. avium, both methods were carried out following the guidelines of the Clinical and Laboratory Standards Institute for fastidious Gram-negative organisms (CLSI, 2002).

Briefly, for the disk diffusion method, colonies grown on Columbia agar plates supplemented with 5\% sheep blood were suspended in Mueller-Hinton broth (Oxoid, Basingstoke, Hampshire, UK). Turbidity of the suspension was adjusted to $0.5 \mathrm{McF}$ arland standards. The suspension was swabbed onto the surface of Mueller Hinton agar (Oxoid, Basingstoke, Hampshire, UK) enriched with 5\% sheep blood, and antibiotic discs were applied. Plates were incubated at $37{ }^{\circ} \mathrm{C}$ for 24 (B. avium) or 48 (O. rhinotracheale) h.

The results were interpreted on the basis of the breakpoints given either in the CLSI document M31-S1 (CLSI, 2004) or in the CLSI document M100-S21 (CLSI, 2011). For antibiotics not found in these documents, the breakpoints used by Murthy et al. (2008) were adopted.

For the determination of the MIC, twofold dilutions of each antibiotic were prepared with final concentrations ranging from $0.03 \mu \mathrm{g} / \mathrm{ml}$ to $64 \mu \mathrm{g} / \mathrm{ml}$. Wells were inoculated with bacterial suspension of log phase cultures in MuellerHinton broth. Turbidity was adjusted to $0.5 \mathrm{McF}$ arland standards and diluted to yield a final concentration of $5 \times 10^{5} \mathrm{CFU} / \mathrm{ml}$. Plates were read after 24 (B. avium) or 48 (O. rhinotracheale) h of incubation at $37^{\circ} \mathrm{C}$. The MIC was defined as the lowest concentration of the antibiotic that inhibited visible growth. Five test replicates of each antimicrobial drug were done.

\section{Results}

The results of the disk diffusion susceptibility test of $O$. rhinotracheale and $B$. avium isolates are shown in Tables 2 and 3, respectively. 


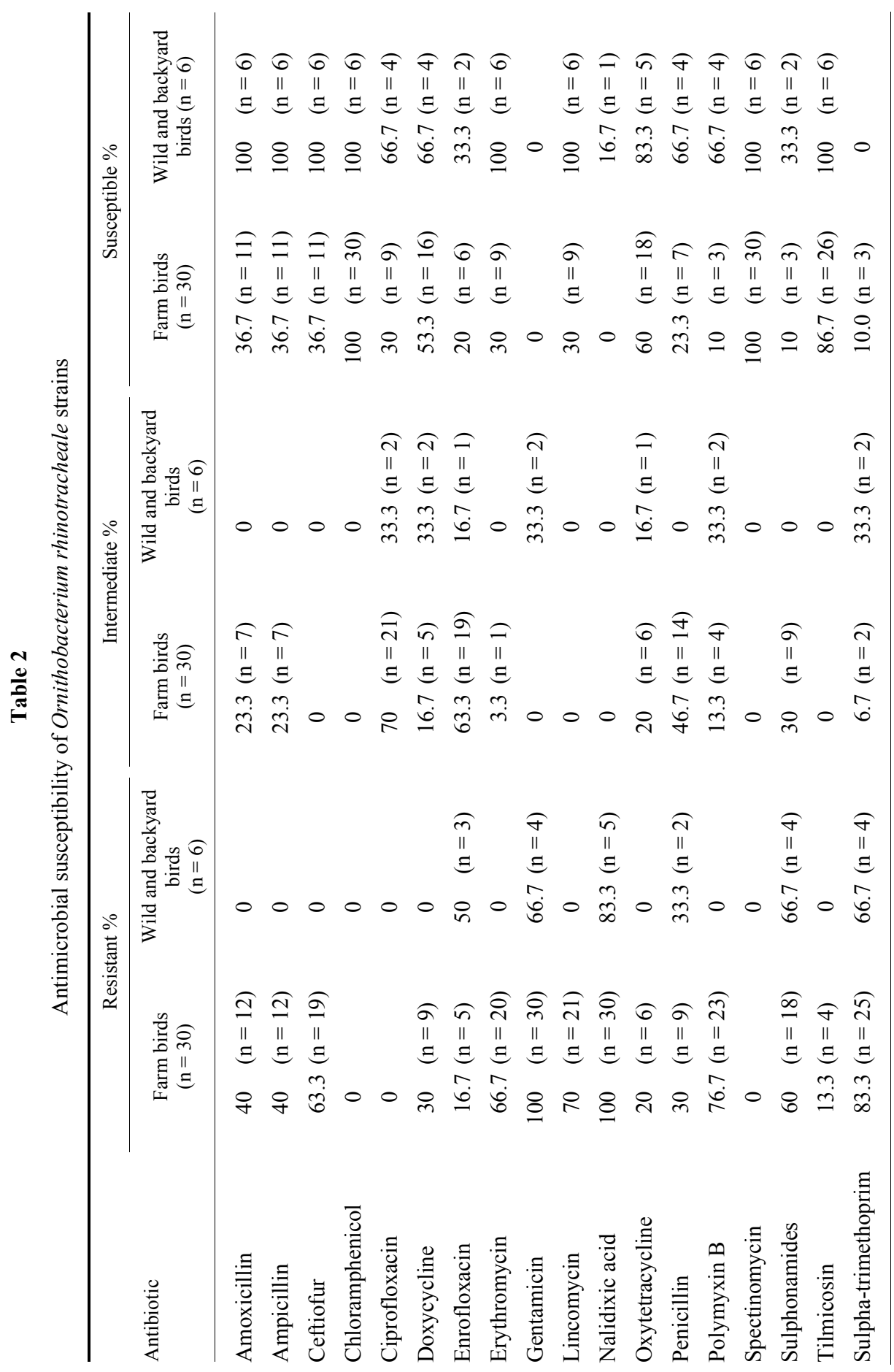




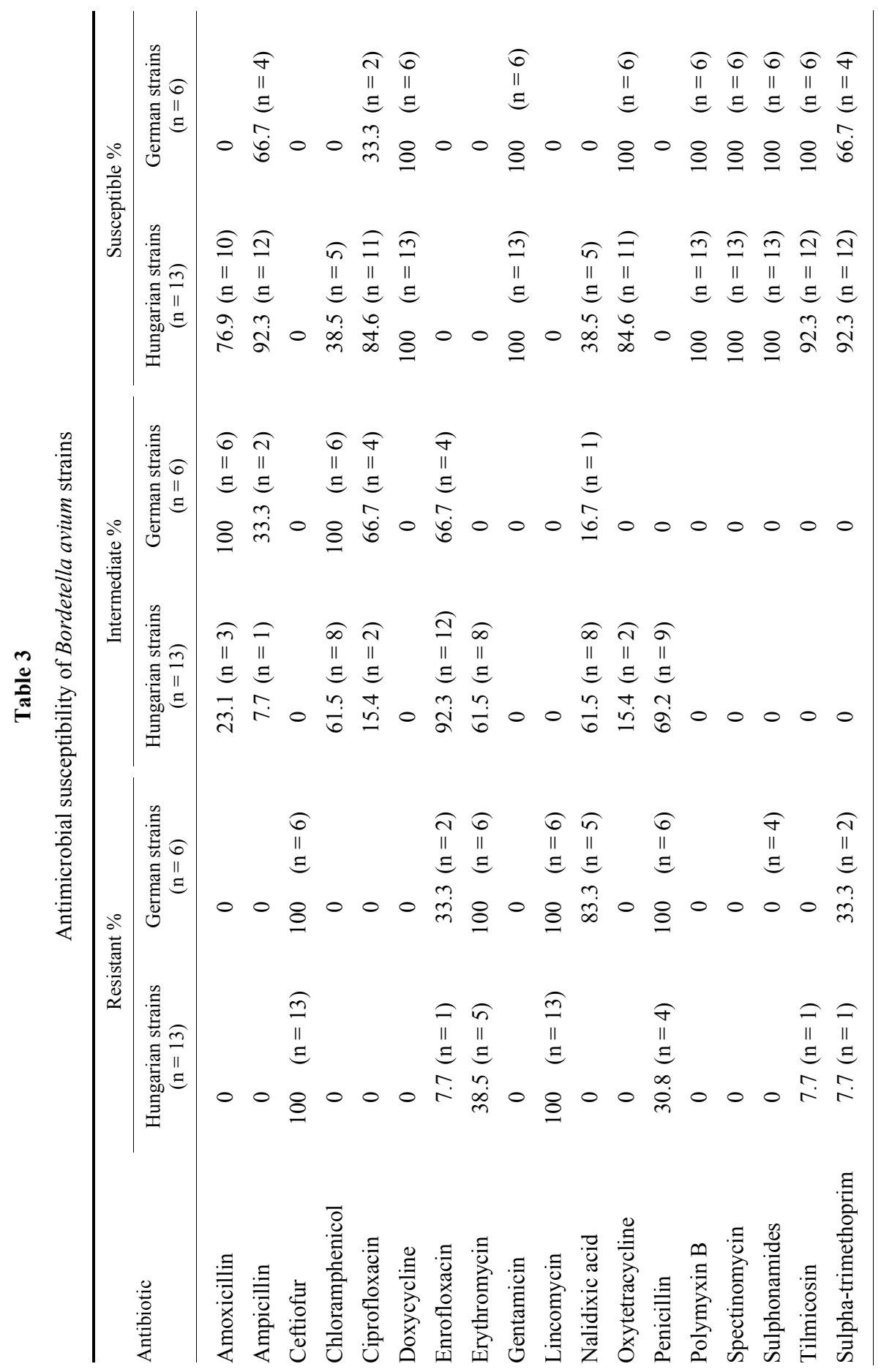


All $O$. rhinotracheale strains were susceptible to chloramphenicol and spectinomycin, and most of them also to tilmicosin. A high percent of the strains were resistant to gentamicin, nalidixic acid, sulphamethoxazole-trimethoprim, and polymyxin B as well as sulphonamides were also among the less effective antibiotics.

The strains isolated from goshawk, sparrowhawk and pigeons were susceptible to a higher number of antibiotics than the strains isolated from poultry. The strain isolated from goshawk was the only strain one susceptible to nalidixic acid and was found to be sensitive to all antibiotics except sulphonamides, while the isolate from sparrowhawk was only strain resistant to nalidixic acid and sulphonamides.

All B. avium strains were resistant to ceftiofur and lincomycin, and susceptible to doxycycline, gentamicin, polymyxin B, spectinomycin and sulphonamides. Amoxicillin, ciprofloxacin, chloramphenicol and oxytetracycline also proved to be effective, although some of the strains showed only moderate susceptibility. Tilmicosin and sulphamethoxazole-trimethoprim were generally efficient, however, resistant strains were also found among the isolates. Nine out of the 13 Hungarian isolates showed intermediate susceptibility to penicillin. The six strains collected in Germany in the 1980s had a distinct resistance pattern: all of them were resistant to penicillin and five of them to nalidixic acid (one showed decreased susceptibility), and all of them were susceptible to ampicillin.

The MIC values were all reproducible within one twofold dilution in the five replicates. The MICs ranged widely for all three antibiotics tested against $O$. rhinotracheale strains, from $0.12 \mu \mathrm{g} / \mathrm{ml}$ to $32 \mu \mathrm{g} / \mathrm{ml}$ in the case of amoxicillin and erythromycin, and $0.6 \mu \mathrm{g} / \mathrm{ml}$ to $32 \mu \mathrm{g} / \mathrm{ml}$ for doxycycline (Table 4). MICs were in the lower range against isolates from wild birds $(0.12 \mu \mathrm{g} / \mathrm{ml}$ for all three antibiotics) and strains from backyard chickens $(0.5 \mu \mathrm{g} / \mathrm{ml}$ and $1 \mu \mathrm{g} / \mathrm{ml}$ for amoxicillin, $0.06 \mu \mathrm{g} / \mathrm{ml}$ and $0.5 \mu \mathrm{g} / \mathrm{ml}$ for doxycycline, and $0.5 \mu \mathrm{g} / \mathrm{ml}$ for erythromycin). $\mathrm{MIC}_{50}$ values were $4 \mu \mathrm{g} / \mathrm{ml}$ for amoxicillin and doxycycline and $8 \mu \mathrm{g} / \mathrm{ml}$ for erythromycin against isolates from farm birds and $0.5 \mu \mathrm{g} / \mathrm{ml}, 0.12 \mu \mathrm{g} / \mathrm{ml}$ and $0.5 \mu \mathrm{g} / \mathrm{ml}$, respectively, against strains from wild and backyard birds.

Table 5 shows the MICs of amoxicillin, doxycycline and erythromycin against $B$. avium isolates. Values ranged from $\leq 0.03 \mu \mathrm{g} / \mathrm{ml}$ to $1 \mu \mathrm{g} / \mathrm{ml}$ for amoxicillin, from $\leq 0.03 \mu \mathrm{g} / \mathrm{ml}$ to $0.12 \mu \mathrm{g} / \mathrm{ml}$ for doxycycline and from $8 \mu \mathrm{g} / \mathrm{ml}$ to $16 \mu \mathrm{g} / \mathrm{ml}$ for erythromycin. The MICs of all three antibiotics against German strains were in the higher range of the overall values $(0.5$ to $1 \mu \mathrm{g} / \mathrm{ml}, 0.06$ to $0.12 \mu \mathrm{g} / \mathrm{ml}$ and $16 \mu \mathrm{g} / \mathrm{ml}$, respectively). $\mathrm{MIC}_{50}$ values were $0.12 \mu \mathrm{g} / \mathrm{ml}$ for amoxicillin, $0.06 \mu \mathrm{g} / \mathrm{ml}$ for doxycycline and $8 \mu \mathrm{g} / \mathrm{ml}$ for erythromycin against Hungarian and $0.5 \mu \mathrm{g} / \mathrm{ml}$ for amoxicillin, $0.06 \mu \mathrm{g} / \mathrm{ml}$ for doxycycline and $16 \mu \mathrm{g} / \mathrm{ml}$ for erythromycin against German strains. 

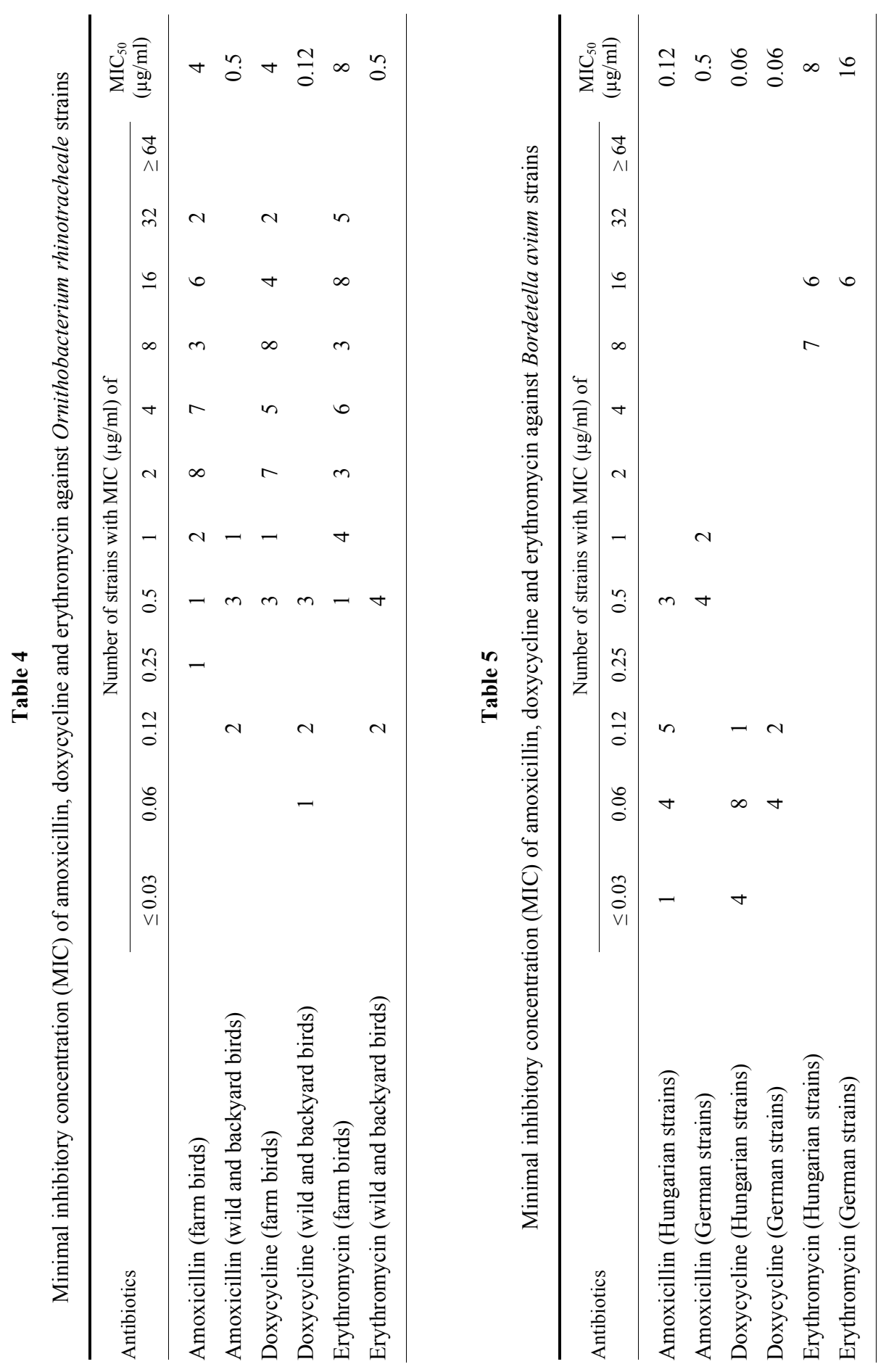

Acta Veterinaria Hungarica 63, 2015 


\section{Discussion}

The antimicrobial susceptibility of $O$. rhinotracheale and $B$. avium has been evaluated in several studies, and resistance seems to vary according to the region of origin. Comparing results from different investigations is complicated because no standard methods and interpretation criteria exist for these microorganisms. Several authors use the CLSI guidelines for fastidious Gram-negative bacteria; however, testing methods and criteria for susceptibility and resistance may differ among reports.

We selected antibiotics so as to allow a comparison of the resistance profiles of our isolates to those described by other authors. Amoxicillin, doxycycline and erythromycin were chosen for further analysis by determining their MIC values because of their diverse efficacy as shown in the disk diffusion tests against $O$. rhinotracheale.

Forty $\%$ and $36.7 \%$ of our isolates were susceptible and resistant, respectively, to amoxicillin and ampicillin, while $23.3 \%$ of the strains showed reduced (intermediate) susceptibility. The majority of the studies found that $O$. rhinotracheale strains isolated worldwide proved to be susceptible to ampicillin (Varga et al., 2001; Malik et al., 2003a; Tsai and Huang, 2006; Murthy et al., 2008), amoxicillin (Tsai and Huang, 2006; Murthy et al., 2008) and chloramphenicol (MohdZain et al., 2008; Murthy et al., 2008). Mohd-Zain et al. (2008) observed an interesting phenomenon when examining the susceptibility patterns of $O$. rhinotracheale strains by the disk diffusion method: $16.7 \%$ of the isolates were susceptible to amoxicillin, and all the strains were resistant to ampicillin. Unfortunately, the authors did not specify the exact method or the breakpoints used for interpreting their results, and only stated that the CLSI guidelines were used.

At the same time, most authors found $O$. rhinotracheale strains to be resistant to gentamicin (Ak and Turan, 2001; Malik et al., 2003a; Soriano et al., 2003; Murthy et al., 2008) and sulphamethoxazole-trimethoprim (Malik et al., 2003a; Tsai and Huang, 2006; Mohd-Zain et al., 2008; Murthy et al., 2008).

Spectinomycin was found to be effective in our study; however, in a previous survey in Hungary it did not inhibit the growth of $O$. rhinotracheale, or inhibited it only in high concentrations (Varga et al., 2001). Malik et al. (2003a) observed both susceptible and resistant strains, depending on the year of isolation. All of the strains isolated in 1996 and 1999 were sensitive to this antibiotic, whereas $80 \%$ of the $O$. rhinotracheale isolates recovered in 1998 were resistant to it. Susceptibility to spectinomycin was not tested for isolates obtained in 2000-2002. Lincomycin did not inhibit the growth of $O$. rhinotracheale strains in Belgium (Devriese et al., 2001), but it was found to be effective against Hungarian isolates (Varga et al., 2001).

The susceptibility of Belgian $O$. rhinotracheale strains to doxycycline varied in the same range as our findings (Devriese et al., 2001). Varga et al. (2001) 
observed low MICs to erythromycin; however, the drug inhibited the growth of $O$. rhinotracheale strains only in high concentrations or not at all in the Netherlands (van Veen et al., 2001). Similarly, the susceptibility of Mexican strains to amoxicillin ranged from $16 \mu \mathrm{g} / \mathrm{ml}$ to $128 \mu \mathrm{g} / \mathrm{ml}$ with only one susceptible isolate at $2 \mu \mathrm{g} / \mathrm{ml}$ (Soriano et al., 2003), and all Dutch isolates were resistant, too $(64 \mu \mathrm{g} / \mathrm{ml})$ (van Veen et al., 2001) whereas elsewhere a wider range $(\leq 0.06 \mu \mathrm{g} / \mathrm{ml}$ to $\geq 64 \mu \mathrm{g} / \mathrm{ml}$ ) was reported (Varga et al., 2001).

The MICs of amoxicillin against strains that have been found to be susceptible by the disk diffusion method varied within a wide range, from 0.12 to $2 \mu \mathrm{g} / \mathrm{ml}$, with strains from wild and backyard birds at the lower end of the range, whereas the MICs against resistant strains were relatively low ( 8 to $32 \mu \mathrm{g} / \mathrm{ml}$ ). The MICs of doxycycline and erythromycin showed a similar pattern.

Our B. avium strains were susceptible to doxycycline, gentamicin, polymyxin B, spectinomycin and sulphonamides, while some of the strains showed reduced (intermediate) susceptibility to ampicillin, chloramphenicol, ciprofloxacin, erythromycin, and oxytetracycline, suggesting a decrease of effectiveness of the latter antibiotics. Bordetella avium strains isolated in Minnesota in 19981999 proved to be sensitive to ampicillin, enrofloxacin and gentamicin, and all four were resistant to erythromycin (Malik et al., 2005). An increasing trend of resistance was seen to erythromycin and sulphamethoxazole-trimethoprim, whereas a decreasing trend of resistance was observed to ampicillin by Malik et al. $(2003 b)$. Resistance to enrofloxacin and gentamicin was consistently high. In another study, B. avium isolates were consistently resistant to penicillin and cefuroxime but susceptible to gentamicin and cefoperazone (Mortensen et al., 1989). Beach et al. (2012) observed high or intermediate levels of resistance to the third-generation cephalosporins and ampicillin. Interestingly, all strains but one were found to be sensitive to penicillin. The authors of this article speculate that this phenomenon might be explained by the lack of the penicillin-binding protein 3 gene in the genome sequence of $B$. avium strain $197 \mathrm{~N}$, which is hitherto the only $B$. avium strain with its whole genome published. Further information on the presence of this gene in other $B$. avium strains would be needed to decide whether this is a unique attribute or is more common in B. avium isolates, and mutagenesis testing is required to confirm this hypothesis. We also found that some of our strains were moderately susceptible to penicillin, which can be explained by either the above assumption or the uncertainties of the breakpoints.

The ranges of MICs against $B$. avium strains were narrower than those against $O$. rhinotracheale isolates in this study, and the values were generally lower. The MICs against German strains were at the higher end of the range for all three antibiotics.

The MIC of erythromycin against B. avium isolates obtained in our study was similar to the results obtained by Mortensen et al. (1989). 
Ornithobacterium rhinotracheale strains isolated from a goshawk and a sparrowhawk were susceptible to all but one (sulphonamides) and two (sulphonamides and nalidixic acid) antimicrobial agents tested, respectively. Their MICs were also lower to all three antibiotics tested in the present study. This result is in accordance with the findings by Devriese et al. (2001), who found that a strain from a rook showed lower MIC values than did isolates from broilers and turkeys. This has been suggested as an evidence for the acquired resistance of strains from commercial poultry, which is believed to be exceptionally frequent in O. rhinotracheale strains (Devriese et al., 2001).

In this study, the MICs against $O$. rhinotracheale strains were in the upper range even if there were many susceptible strains. This is in harmony with the observation that, in the past few years, antibiotic treatment of the disease was seen to become less effective, while the prevalence of $O$. rhinotracheale infections has increased (van Veen et al., 2001).

Mortensen et al. (1989) speculated that the great selective pressure from the extensive use of antimicrobial drugs in commercial flocks contributed to most $B$. avium strains from turkeys showing an increasingly broad spectrum of antimicrobial resistance. The idea that the local use of antibiotics facilitates the emergence of antimicrobial resistance in locally present pathogens is supported by our findings that both $O$. rhinotracheale and $B$. avium strains isolated from the same poultry farms showed similar resistance patterns.

Despite the efforts made in the poultry industry to decrease the use of antibiotics and rely on disease prevention and better management practices, infectious respiratory diseases are still common and cause considerable economic losses. At the same time, the emergence of multi-drug resistance is becoming one of the major medical and veterinary concerns, and the overuse of antibiotics in veterinary medicine has been suggested to contribute to the selection of resistant pathogens. These facts, together with the lack of uniform in vitro susceptibility of these pathogens, underline the importance of the adequate and prudent application of antibiotic therapy based on proper antimicrobial susceptibility testing.

\section{Acknowledgements}

This project was supported by the Hungarian Scientific Research Fund (OTKA K108632). The authors thank László Makrai and Éva Gyuris for supplying some of the strains examined in this study.

\section{References}

Ak, S. and Turan, N. (2001): Antimicrobial susceptibility of Ornithobacterium rhinotracheale isolated from broiler chickens in Turkey. Veterinarski Arhiv 71, 121-127. 
Beach, N. M., Thompson, S., Mutnick, R., Brown, L., Kettig, G., Puffenbarger, R., Stockwell, S. B., Miyamoto, D. and Temple, L. (2012): Bordetella avium antibiotic resistance, novel enrichment culture, and antigenic characterization. Vet. Microbiol. 160, 189-196.

Clinical and Laboratory Standards Institute (formerly: National Committee for Clinical Laboratory Standards) (2002): Performance Standards for Antimicrobial Disk and Dilution Susceptibility Tests for Bacteria Isolated from Animals: Approved Standard. Second edition. NCCLS document M31-A2. National Committee for Clinical Laboratory Standards, Wayne, PA.

Clinical and Laboratory Standards Institute (2004): Performance Standards for Antimicrobial Disk and Dilution Susceptibility Tests for Bacteria Isolated from Animals: Informational Supplement. CLSI document M31-S1. Clinical and Laboratory Standards Institute, Wayne, PA

Clinical and Laboratory Standards Institute (2011): Performance Standards for Antimicrobial Susceptibility Testing: Twenty-first Informational Supplement. CLSI document M100-S21. Clinical and Laboratory Standards Institute, Wayne, PA.

Devriese, L. A., De Herdt, P. and Haesebrouck, F. (2001): Antibiotic sensitivity and resistance in Ornithobacterium rhinotracheale strains from Belgian broiler chickens. Avian Pathol. 30, 197-200.

Malik, Y. S., Olsen, K., Kumar, K. and Goyal, S. M. (2003a): In vitro antibiotic resistance profiles of Ornithobacterium rhinotracheale strains isolated from Minnesota turkeys during 19962002. Avian Dis. 47, 588-593.

Malik, Y. S., Olsen, K., Chander, Y. and Goyal, S. M. (2003b): Antimicrobial resistance in bacterial pathogens isolated from turkeys in Minnesota from 1998 to 2002. Int. J. Appl. Res. Vet. Med. 14, 506-511.

Malik, Y. S., Chander, Y., Gupta, S. C. and Goyal, S. M. (2005): A retrospective study on antimicrobial resistance in Mannheimia (Pasteurella) haemolytica, Escherichia coli, Salmonella species, and Bordetella avium from chickens in Minnesota. J. Appl. Poult. Res. 14, 506-511.

Mohd-Zain, Z., Lin Jee, T. and Jusoff, K. (2008): Phenotypic characteristics, antibiotic susceptibility and pathogenicity of Ornithobacterium rhinotracheale. WSEAS Transact. Biol. Biomed. 7, 133-142.

Mortensen, J. E., Brumbach, A. and Shryock, T. R. (1989): Antimicrobial susceptibility of Bordetella avium and Bordetella bronchiseptica isolates. Antimicrob. Agents Chemother. 33, 771-772.

Murthy, T. R. K. G., Dorairajan, N., Balasubramanium, G. A., Dinakaran, A. M. and Saravanabava, K. (2008): In vitro antibiotic sensitivity of Ornithobacterium rhinotracheale strains isolated from laying hens in India. Vet. Arhiv 78, 49-56.

Raffel, T. R., Register, K. B., Marks, S. A. and Temple, L. (2002): Prevalence of Bordetella avium infection in selected wild and domesticated birds in the Eastern USA. J. Wildl. Dis. 38, 40-46.

Register, K. B. and Yersin, G. (2005): Analytical verification of a PCR assay for identification of Bordetella avium. J. Clin. Microbiol. 43, 5567-5573.

Soriano, V. E., Vera, N. A., Salado, C. R., Fernández, R. P. and Blackall, P. J. (2003): In vitro susceptibility of Ornithobacterium rhinotracheale to several antimicrobial drugs. Avian Dis. 47, 476-480.

Tanyi, J., Bistyák, A., Kaszanyitzky, É., Vetési, F. and Dobos-Kovács, M. (1995): Isolation of Ornithobacterium rhinotracheale from chickens and turkeys with respiratory disease. Preliminary report [in Hungarian, with English abstract]. Magyar Állatorvosok Lapja 50, 328-330.

Tsai, H. J. and Huang, C. W. (2006): Phenotypic and molecular characterization of isolates of $\mathrm{Or}$ nithobacterium rhinotracheale from chickens and pigeons in Taiwan. Avian Dis. 50, 502-507.

van Empel, P. C. M. and Hafez, H. M. (1999): Ornithobacterium rhinotracheale: a review. Avian Pathol. 28, 217-227.

van Veen, L., Hartman, E. and Fabri, T. (2001): In vitro antibiotic sensitivity of strains of Ornithobacterium rhinotracheale isolated in the Netherlands between 1996 and 1999. Vet. Rec. 149, 611-613.

Varga, J., Fodor, L. and Makrai, L. (2001): Characterisation of some Ornithobacterium rhinotracheale strains and examination of their transmission via eggs. Acta Vet. Hung. 49, 125-130. 